\title{
An Overview of Nutritional Knowledge about Anemia Among Students of Universitas Negeri Semarang
}

\author{
Levia Arkananta Sarjono ${ }^{1}$, Milda Hasna $^{2}$, Natalia Desy Putriningtyas ${ }^{3}$ \\ \{viaarkananta@students.unnes.ac.id ${ }^{1}$, mildahasna02@ students.unnes.ac.id ${ }^{2}$, \\ nataliadesy@mail.unnes.ac.id $\left.{ }^{3}\right\}$ \\ Universitas Negeri Semarang, Semarang, Indonesia ${ }^{1,2,3}$
}

\begin{abstract}
This study was aimed to provide an overview of nutritional knowledge about anemia among students of Universitas Negeri Semarang. Anemia is a condition of red blood cells deficiency. Anemia characterized by low hemoglobin levels, less than $12 \mathrm{~g} /$ $\mathrm{dl}$ in women and $13 \mathrm{~g} / \mathrm{dl}$ in men. The prevalence of anemia in Indonesia in $2013 \mathrm{in}$ women aged $15-24$ years was $18.4 \%$, then increased to $32 \%$ in 2018 . One of the factors that influence the prevalence of anemia is the level of knowledge of each individual. Knowledge will affect behavior, selection of foodstuffs and even life patterns. This study is a cross sectional study with the selection of respondents using the covenient sampling method through distributing questionnaires.
\end{abstract}

Keywords: Anemia, Teenagers, Knowledge.

\section{Introduction}

Anemia is still a nutritional problem in Indonesia. Anemia is a condition of red blood cells deficiency characterized by a hemoglobin level of less than $12 \mathrm{~g} / \mathrm{dl}$ in women and $13 \mathrm{~g} /$ dl in men. Basic Health Research Data (Riskesdas) in 2013 for the incidence of anemia in women aged 15-24 years of $18.4 \%$ then increased to $32 \%$ in 2018 [1].

Young women are reported to have a 10 times higher potential for developing anemia than young men [2]. The type of anemia that many young women experience is iron deficiency anemia. The risk of anemia in young women can be influenced by diet and physiological functions such as the menstrual cycle experienced by young women [3]. Menstruation experienced by young women causes a decrease in iron stores in the body. This decreasing iron store is further exacerbated if young women restrict food consumption on the pretext of maintaining body shape [4].

Iron is a mineral that plays a role in the formation of hemoglobin. Hemoglobin is a part of red blood cells that functions to transport oxygen and nutrients to all parts of the body's cells. If the hemoglobin content in the body is low, it will result in an inadequate supply of oxygen and nutrients so that which will have an impact such as lethargy, weakness, fatigue and ultimately disrupting activity [5].

Students as a form of representation from youth groups are educated and very easily get various information related to health and nutrition. Based on the results of research conducted by Dewi [6] with the title "Diet and Incidence of Anemia in Students Living in Boarding Schools", it was found that the incidence of anemia in female students showed that most of the respondents did not experience anemia, as many as $61 \%$ and $39 \%$ had anemia. Respondents 
who experience anemia are due to lack of protein consumption, like to consume fast food and junk food, and often consume packaged tea drinks. Knowledge is the result of a person sensing an object. Knowledge is obtained through observation with the five senses, both the senses of sight, hearing, smell, taste, and touch. Knowledge of cognitive is very dominant and very important in the formation of one's actions [7]. Knowledge will affect behavior, selection of foodstuffs, and even life patterns.

\section{Methods}

This research is a cross-sectional study that was conducted in March 2021 at Universitas Negeri Semarang. The selection of respondents using the convenient sampling method through distributing questionnaires. The questionnaire contains closed questions regarding nutritional knowledge on the incidence of anemia, a Likert scale, and is distributed online using the google form. The number of respondents in this study was calculated using a sample size formula for a single correlation coefficient to obtain a sample of 137 people.

Statistical analysis used nominal and categorical data to determine the descriptive description of Universitas Negeri Semarang students.

\section{Result and Discussion}

Table 1. Descriptive description of respondents

\begin{tabular}{ll}
\hline Variable $(\mathrm{n}=137$ people $)$ & mean \pm SD \\
\hline Age $($ years $)$ & $19.46 \pm 1.08$ \\
Weight $(\mathrm{kg})$ & $55 \pm 19.22$ \\
Height $(\mathrm{cm})$ & $159.07 \pm 11.69$ \\
Nutritional Status $(\mathrm{kg} / \mathrm{m} 2)$ & $24.83 \pm 44.29$ \\
\hline
\end{tabular}

Table 1 shows a description of the respondents in this study. The respondents of this study were 137 students of Universitas Negeri Semarang with an average age of $19.46 \pm 1.08$ years. The mean body weight and height of the respondents were $55 \pm 19.22 \mathrm{~kg}$ and $159.07 \pm 11.69$ $\mathrm{cm}$, respectively. The average nutritional status of respondents was at $24.83 \pm 44.29 \mathrm{~kg} / \mathrm{m} 2$ and was included in the obesity category.

Obesity is the result of an imbalance in the amount of calorie intake that is put into the body with energy output, resulting in excessive fat accumulation. Obesity in adolescents can increase the risk of cardiovascular disease in adulthood because of its association with metabolic syndromes consisting of insulin resistance and hyperinsulinemia, glucose intolerance and diabetes mellitus, dyslipidemia, hyperuricemia, fibrinolytic disorders, and hypertension [8].

Table 2. Results of respondents' nutritional knowledge

\begin{tabular}{ll}
\hline Variable $(\mathbf{n}=137)$ & Distribution Frequency $(\%)$ \\
\hline Gender & \\
Male & $26(18.6 \%)$ \\
Women & $111(79.3 \%)$ \\
\hline
\end{tabular}




\begin{tabular}{ll}
\hline Frequency of eating & \\
1 x / day & $4(2.9 \%)$ \\
2-3 times / day & $28(91.4 \%)$ \\
$>3$ times / day & $5(3.6 \%)$ \\
\hline Number of servings of vegetables / fruit & \\
Never & $21(15.3 \%)$ \\
1 serving / week & $1(0.7 \%)$ \\
2-5 servings / week & $24(18 \%)$ \\
7 servings / week & $91(66 \%)$ \\
\hline Consume according to the contents of "Piringku" & \\
Not & $48(34.3 \%)$ \\
Maybe & $59(42.1 \%)$ \\
Yes & $30(21.4 \%)$ \\
\hline Tea / coffee frequency & \\
Never & $24(17.1 \%)$ \\
1x / week & $39(27.9 \%)$ \\
2-5x / week & $50(35.7 \%)$ \\
$7 x$ / week & $24(17.1 \%)$ \\
\hline Exercise frequency & \\
Never & $43(30.7 \%)$ \\
1-2x / week & $69(49.3 \%)$ \\
3-5x / week & $21(15 \%)$ \\
$7 x$ / week & $4(2.9 \%)$ \\
\hline Sleep duration & \\
1-2 hours / day & $5(3.6 \%)$ \\
3-5 hours / day & $1(0.7 \%)$ \\
8 hours / day 8 hours / day & $67(47.9 \%)$ \\
\hline Screentime & $64(45.8 \%)$ \\
<2 hours / day & \\
2-4 hours / day & $58(41.4 \%)$ \\
5-6 hours / day 8 hours / day & $1(0.7 \%)$ \\
\hline Education about anemia & $19(13.6 \%)$ \\
Not yet & $59(42.1 \%)$ \\
I did & \\
Importance of Fe tablets & $76(54.3 \%)$ \\
Disagree & $61(43.7 \%)$ \\
Less agree & \\
Agree & $92(3.6 \%)$ \\
\hline & \\
& \\
\hline
\end{tabular}

Table 2. shows a description of the respondents who filled out the knowledge questionnaire about anemia. The majority of respondents in this study were women with a total of 111 people $(79.4 \%)$. The incidence of anemia is reported to occur mostly in young women Research conducted by Simanungkalit [1] with the title "Knowledge and Consumption Behavior of Young Women Associated with Anemia Status" which was carried out on Depok high school students aged 12-16 years in the early adolescent category as many as 142 students $(82.6 \%)$ and $17-25$ years old or in the category 30 female students $(17.4 \%)$ showed that there were 120 students $(69.8 \%)$ with less Fe intake, while 52 students $(30.2 \%)$ had good $\mathrm{Fe}$ intake. The results of the level of knowledge regarding blood added tablets (signed) were found that 86 students (50\%) had less knowledge of TTD (Blood Added Tablets), while 
respondents who had good knowledge of blood-booster tablets (Tablets Add Blood) were 86 students $(50 \%)$. From the results of the research that has been done, the researchers concluded that the knowledge of anemia is the main factor of anemia in adolescent girls.

The frequency of eating shows how much the respondent eats in a period of one day. The majority of respondents said that within one day they have a habit of eating 2-3 times/day. However, the frequency of eating habits also needs to be balanced by paying attention to the diversity of consumption and energy adequacy. Research on "Food Consumption of Indonesian Citizens in terms of Balanced Nutrition Norms (Food Consumption In Term Of The Norm Of Balanced Nutrition)" was conducted by Safitri [9]. The conclusion is that the food consumption of the Indonesian population in general still does not fulfill the first pillar of the message of balanced nutrition. This can be seen from the quality and quantity of food consumption of the population from the age of 6 years and over, with diversity, proportion and adequacy obtained only 1.43 percent. Although the diversity is good, in terms of proportion and adequacy the percentage is still small.

In Indonesia, there is the term "the contents of my plate", which is a balanced nutrition guide aimed at the Indonesian people to provide an understanding of the importance of balanced nutritional intake. The portion composition in my one-meal plate includes staple foods as much as $2 / 3$ of a $1 / 2$ plate, side dishes $1 / 3$ of a $1 / 2$ plate, fruits $1 / 3$ of a plate, and vegetables $2 / 3$ of a $1 / 2$ plate Table 2 shows that As many as 59 people (42.3\%) thought that their meal arrangement was by my plate and even $66 \%$ said that every day they consume fruits/vegetables. Green vegetables are a source of iron and consumption of vegetables and fruit is one strategy in increasing iron intake. Non-heme iron itself is widely available in plantbased food sources. Non-heme iron is generally found in foods derived from plants such as vegetables, seeds, nuts, fruits, cereal, chocolate, and wheat flour [10]. As many as 107 students $(76.6 \%)$ could name the exact source of iron, either from vegetable or animal sources.

The nutritional status of respondents in this study indicated obesity. This possible link with obesity is in line with the description of exercise habits. Table 2 shows that the majority of respondents exercise 1-2x / week and the majority have a sleep duration of 8 hours/day. Sports and physical activity are different. Physical activity is all body movements that increase energy or energy expenditure and burn calories [11]. Physical activity can be in the form of light activities or daily activities. While the sport itself is a form of effort to encourage, awaken, develop, and build physical strength. The sport itself comes from the Javanese language, namely through which means olah and rogo which means the body [12]. Sleep is a state where someone is in the subconscious, but can still be awakened by giving a stimulation. Sleep is an important factor in maintaining physical and mental health. The duration of sleep or the length of time a person sleeps greatly affects their health condition. Each age group has a different recommendation for sleep duration as needed. For adolescents aged 14-17 years, the recommended sleep duration is 8-10 hours per day, while for adolescents aged 18-25 years, the ideal sleep duration is 7-9 hours per day [13]. The majority of respondents admitted that they had never received education about anemia but they thought that Fe tablets were one of the strategic steps in fighting anemia. Foods containing heme iron have a high bioavailability of $20-30 \%$ or more. This is because heme iron is available in the form of iron $\mathrm{Fe} 2+$ (ferrous) which can be absorbed directly and is not affected by its absorption by other substances [14]. On the other hand, the bioavailability of non-heme iron is lower than the bioavailability of heme iron. The bioavailability of non-heme iron is influenced by the presence or absence of inhibitor compounds such as phytates, tannins, etc. [15].

$\mathrm{Fe}$ tablet is a blood booster tablet. The provision of Fe tablets is one way to maintain hemoglobin levels in the body, especially for young women and pregnant women. This is due 
to the high level of iron requirements for both of them. Fe tablets are recommended to be consumed regularly to reduce the chance of anemia. The consumption of Fe tablets is very important, especially during menstruation and during pregnancy. The absorption of iron in the body will be optimal if it is accompanied by the consumption of organic acids such as vitamin C [16].

\section{Conclusion}

This research is a descriptive study on the description of anemia knowledge among students of Universitas Negeri Semarang. Recommendations that can be made are the importance of continuous education on anemia so that students take part in protecting themselves and the environment.

Acknowledgments. This research was conducted with the assistance of the Sports Science Faculty, Universitas Negeri Semarang.

\section{References}

[1] Simanungkalit, S.F. dan O.S. Simarmata. 2019. Pengetahuan dan Perilaku Konsumsi Remaja Putri yang Berhubungan dengan Status Anemia. Buletin Penelitian Kesehatan, 47(3) : 175-182

[2] Dieniyah, P., M.M. Sari, dan I. Avianti. 2019. hubungan Tingkat Pengetahuan Tentang Anemia dengan Kejadian Anemia pada Remaja Putri di SMK Analisis Kimia Nusa Bangsa Kota Bogor Tahun 2018. PROMOTOR Jurnal Mahasiswa Kesehatan Masyarakat, 2(2) : 151-158.

[3] Sediaoetama, A.D. 2006. Ilmu Gizi Untuk Mahasiswa dan Profesi Jilid II. Dian Rakyat. Jakarta

[4] Apriyanti, F..2019. Hubungan Status Gizi Dengan Kejadian Anemia pada Remaja Putri SMAN 1 Pangkalan Kerinci Kabupaten Pelalawan Tahun 2019. Jurnal Doppler Univrsitas Pahlawan TuankuTambusi, 3(2) : 18-21

[5] Anamisa, D.R..2015. Rancang Bangun Metode OTSU Untuk Deteksi Hemoglobin

[6] Ayu Dwi Putri Rusman. (2018). Pola Makan Dan Kejadian Anemia Pada Mahasiswi Yang Tinggal Di Kos-Kosan. Jurnal Ilmiah Manusia Dan Kesehatan, 1(2). https://doi.org/10.31850/makes.v1i2.141

[7] Notoatmodjo, S. 2011. Kesehatan Masyarakat. Rineka Cipta. Jakarta

[8] Hendra, C., Manampiring, A. E., \& Budiarso, F. (2016). Faktor-Faktor Risiko Terhadap Obesitas. Jurnal E-Biomedik, 4(1), 2-6

[9] Safitri, A., Jahari, A. B., \& Ernawati, F. (2016). Konsumsi Makanan Penduduk Indonesia Ditinjau Dari Norma Gizi Seimbang (Food Consumption In Term Of The Norm Of Balanced Nutrition). Penelitian Gizi Dan Makanan, 39(2), 87-94

[10] Arima, L.A.T., E.A. Murbawani, dan H.S. Wijayanti. 2019. Hubungan Asupan Zat Besi Non-Heme dan Fase Menstruasi dengan Serum feritin Remaja Putri. Journal of Nutrition College, 8(2) : 87-94

[11] Oktriani, S., I. Solihin, dan L. Komariyah. 2019. Physical Activity in Elderly: An Analysis of Type of Sport Taken by Elderly in Bandung. Jurnal Pendidikan Jasmani dan Olahraga, 4(1) : 62-67 
[12] Suwarna, A.H. dan Widiyanto. 2016. Perbedaan Pola Tidur antara Kelompok Terlath dan Tidak Terlatih. MEDIKORA, 15(1) : 85-95

[13] Jamshidi, L., L. Karimi, A. Seif, and H. Vazini. 2017. The Relationship between Anthropometric Factors and Iron Deficiency Anemia Factors. Nov Biomed, 5(2) : 5964.

[14] Brooker C. Kamus Saku Keperawatan. Jakarta: EGC; 2001

[15] Andaruni, N.Q.R. dan B.Q. Nurbaety. 2018. Efektivitas Pemberian Tablet Zat Besi (Fe), Vitamin C, dan Jus Buah Jambu Biji terhadap Peningkatan Kadar Hemoglobin (Hb) Remaja Putri di Universitas Muhammadiyah Mataram. Midwifery Journal, 3(2) : 104-107

[16] Mutohir, C. 1992. UU Sistem Keolahragaan Nasional. Sunda Klapa Pustaka. Jakarta. 